\title{
Tomato Early Seedling Height Control Using a Paclobutrazol Seed Soak
}

\author{
Juan P. Brigard, Richard L. Harkess, ${ }^{1}$ and Brian S. Baldwin \\ Mississippi State University, Department of Plant and Soil Sciences, Box 9555 , \\ Mississippi State, MS 39762
}

\begin{abstract}
Additional index words. Bonzi, Solanum lycopersicum, hypocotyl, light, seed treatment, triazole, plant growth regulator
\end{abstract}

\begin{abstract}
Tomato seedling hypocotyls elongate rapidly after germination resulting in weak seedlings. The effects of $0,250,500,750$, or $1000 \mathrm{mg}$ paclobutrazol (PB)/L seed soak and soaking times from 1 to 12 hours on tomato (Solanum lycopersicum L.) seed germination, seedling growth, and plant growth were tested. Adequate height control was obtained with $250 \mathrm{mg} \mathrm{PB} / \mathrm{L}$ while soaking time did not affect seedling growth. In a second experiment, $P B$ was tested at $0,50,100,150,200$, or $250 \mathrm{mg} P B / L$ soaking the seed for 1 hour. A concentration of $P B$ at $100 \mathrm{mg} \cdot \mathrm{L}^{-1}$ provided optimum control of hypocotyl elongation with minimal residual effect on subsequent plant growth. In a third experiment, seed soaked at the different $P B$ concentrations were germinated and grown under light intensities of $0.09,50,70$, or $120 \mu \mathrm{mol} \cdot \mathrm{m}^{-2} \cdot \mathrm{s}^{-1}$. Seedlings grown under $0.09 \mu \mathrm{mol} \cdot \mathrm{m}^{-2} \cdot \mathrm{s}^{-1}$ were not affected by $P B$ treatment and did not develop an epicotyl. PB seed soak treatment gave greater growth suppression under $50 \mu \mathrm{mol} \cdot \mathrm{m}^{-2} \cdot \mathrm{s}^{-1}$ than under the two higher light levels. Soaking tomato seeds in $100 \mathrm{mg} \mathrm{PB/L}$ for 1 hour prevented early hypocotyl stretch of tomato seedlings with no long term effects on plant growth. This treatment effectively prevented excessive hypocotyl elongation when seeds were germinated under low PAR while not over controlling elongation under high PAR conditions.
\end{abstract}

Seedlings with excessive hypocotyl elongation are more likely to suffer mechanical damage when using automated transplanting. Seedlings of Lycopersicon, Celosia, Cosmos, Tagetes, Dahlia, Zinnia, and other species tend to elongate rapidly after germination and emergence resulting in poor quality plugs. The majority of the initial elongation in these species is in the hypocotyl.

Success in automated transplanting is limited by the quality of the initial plugs. Styer and Koranski (1997) described high quality plugs as having a strong root system, well branched, not excessively tall, not chlorotic, no delay in flowering, and an absence of pests and diseases. Tall plugs tend to be damaged in the transplanting process as they are softer and more easily bruised or broken. A well developed root system is necessary to hold the plug substrate together during transplanting.

Gibberellins (GA) play an important role in hypocotyl elongation (Toyomasu et al., 1992, 1993). Bensen et al. (1990) found that endogenous $\mathrm{GA}_{1}$ concentration was directly proportional to elongation rate of soybean hypocotyls. Controlling GAactivity is considered critical in controlling seedling height.

Two primary methods of height control, environmental and chemical, are used in commercial production (Passian and Bennett,

Received for publication 19 Dec. 2005. Accepted for publication 25 Jan. 2006. Contribution of the Mississippi Agricultural and Forestry Experimental Station journal article J-10686. Mention of a trademark, or a proprietary product does not constitute a guarantee or warranty of the product and does not imply its approval to the exclusion of other products that may also be suitable.

${ }^{1}$ Corresponding author; e-mail rharkess@pss.msstate.edu.
2001). The environment can be regulated to control height in plugs by modifying temperature, light quality and quantity, nutrition levels, and water (Dole and Wilkins, 1999). Tomato seedlings generally can be kept short by careful moisture management, high light intensity, and negative DIF, however, the tomato hypocotyl often elongates quickly during Stages I and II plug production. While the environment can be manipulated to control height, problems arise if good environmental control is unavailable. Environmental control is most effective after emergence. If not timed accurately, hypocotyl extension can be extensive. The use of environmental control is also limited at certain times of the year due to local climates.

Chemical plant growth regulators can also control seedling height. Triazoles are highly effective plant growth regulators inhibiting GA synthesis (Davis et al., 1988; Fletcher and Hofstra, 1990; Arteca, 1996). Two commercially available triazole growth regulators are uniconazole sold as Sumagic (Valent USA, Richardson, Tex.) and paclobutrazol (PB) sold as Bonzi (Syngenta Professional Products, Greensboro, N.C.). PB absorption through the roots is very effective, moving to young shoots acropetally with translocation primarily through the xylem. Pasian and Bennett (2001) soaked seeds of Tagetes patula 'Bonanza Gold' and Pelargonium spp. 'Cherry Orbit' in solutions of $\mathrm{PB}$ at 0,500 , or $1000 \mathrm{mg} \cdot \mathrm{L}^{-1}$ a.i for 6,16 , or $24 \mathrm{~h}$. They found that increasing the $\mathrm{PB}$ concentration decreased germination and speculated that this was due to the diffusion of PB into the seed during imbibition inhibiting germination. Soaking the seed in PB for 6 or 16 $\mathrm{h}$ did not affect the percentage of usable plugs, however, the 24-h soak reduced the number of usable plugs. In most cases, increasing PB concentrations resulted in increasing suppression of growth. The authors speculated that $\mathrm{PB}$ adhering to the seedcoat entered the roots causing growth suppression. Pill and Gunter (2001) found that priming seed of Tagetes in a solution of $1000 \mathrm{mg} \mathrm{PB} / \mathrm{L}$ was more effective at suppressing growth than either a drench or a foliar application. They also concluded that the residual effect, i.e., effect on post-transplant growth, was minor when seeds were primed versus a drench or foliar spray.

We conducted studies to determine the PB concentration and soaking time of a preplant seed soak that would prevent early tomato seedling stretch in plug production while minimizing the possible long-term PB effects on seedling development and transplant performance. In addition, we examined the effects of the PB seed soak on hypocotyl elongation under different light conditions.

\section{Materials and Methods}

PB concentration and duration. Batches of 50 seeds were counted and weighed from a 10,000 seed lot of hybrid tomato (Solanum lycopersicum L.) 'Better Boy', (Ball Seed Co., Chicago, Ill.). Each seed batch was weighed before and after treatment. For the treatment of the seed, a complete randomized design with two factors was used.

The seed batches were placed in sealed $20 \mathrm{~mL}$ assay tubes and soaked in $5 \mathrm{~mL}$ of solutions at $0,250,500,750$, or $1000 \mathrm{mg} \mathrm{PB} / \mathrm{L}$ for $1,2,3$, $4,5,6,7,8,9,10,11$, or $12 \mathrm{~h}(5 \times 12$ factorial, respectively). Each treatment was replicated three times. The tubes containing the seed were placed in the dark at $20^{\circ} \mathrm{C}$ on a shaker table to keep the solutions aerated. Treated seed were removed from the tubes, surface dried on blotting paper, and their weight recorded. Seed were then oven dried at $30^{\circ} \mathrm{C}$ for $3 \mathrm{~d}$ and reweighed. Initial PB solution electrical conductivity was measured using a conductance meter (model 35; Yellow Springs Instrument Co., Inc., Yellow Springs, Ohio). Electrical conductivity of the $\mathrm{PB}$ solution was measured again after the seed were removed.

Ten treated seeds from each treatment were sown 1 seed per cell in 288 cell plug flats $(8.5$ $\mathrm{mL} /$ cell). The plug flats were divided with tape to delineate divisions of ten cells. The flats were filled with Plug-Mix PGX (Premiere Horticulture Inc., Red Hill, Pa.), seeded, and seed was covered to about $5 \mathrm{~mm}$ depth with medium grade vermiculite. The treatments with three replications were assigned in a complete randomized design to the divisions in the 288 cell flats. The flats were placed on greenhouse benches on a capillary mat and subirrigated for the first $15 \mathrm{~d}$. Temperatures were set at 20 ${ }^{\circ} \mathrm{C}$ night and $21{ }^{\circ} \mathrm{C}$ day. The seedlings were grown in a glass glazed greenhouse with no shading. In this study, emergence was defined as when the seedling hypocotyl emerged from the soil and the cotyledonary leaves were fully expanded. After $15 \mathrm{~d}$, the flats were removed from the capillary mat and irrigated overhead. Fertilization was applied every third day at $200 \mathrm{mg} \mathrm{N} / \mathrm{L}$ from 20N-4.4P-16.6K (Peters Professional, Scotts Co., Marysville, Ohio). 
Emergence counts were taken at 7 and 14 d after sowing. At $35 \mathrm{~d}$ after sowing, three seedlings of each treatment replication were destructively harvested to calculate mean hypocotyl length and mean total seedling height both measured from the soil surface.

Residual PB effects. Batches of 50 seeds were treated with $0,50,100,150,200$, or 250 $\mathrm{mg} \mathrm{PB} / \mathrm{L}$ for $1 \mathrm{~h}$. Each treatment was replicated three times. Seed were soaked following the same procedure used in Experiment I. After one hour, seed were removed from the tubes, surface dried, placed in envelopes, and dried at $30{ }^{\circ} \mathrm{C}$ for $3 \mathrm{~d}$.

Ten seeds per treatment replication were sown and grown as in the first experiment. The treatments were randomly assigned to the flats as a randomized complete block. After $35 \mathrm{~d}$ from sowing, three seedlings from each treatment replication were destructively harvested and measured for hypocotyl length and total seedling height as previously described.

Three additional seedlings from each treatment replication were transplanted each into individual $15-\mathrm{cm}$-diameter, $1.5-\mathrm{L}$ pots and grown in a glass glazed greenhouse without shade to determine long term effects of the PB treatment. Greenhouse temperatures were set at $20^{\circ} \mathrm{C}$ night and $21^{\circ} \mathrm{C}$ day. Fertilization at 200 $\mathrm{mg} \mathrm{N} / \mathrm{L}$ from $20 \mathrm{~N}-4.4 \mathrm{P}-16.6 \mathrm{~K}$ was applied at every irrigation except weekends when water was applied. As plants flowered, length of each of the first ten internodes was measured.

Data collected in the PB concentration and residual effects experiments were analyzed using the regression procedure of SAS (SAS Institute, Cary, N.C.).

Photosynthetically active radiation (PAR) intensity. Batches of 50 seeds were soaked in $0,12.5,25,37.5,50,100,150,200$, or $250 \mathrm{mg}$ $\mathrm{PB} / \mathrm{L}$ for $1 \mathrm{~h}$ following the same procedure as in the residual PB effects experiment. In this experiment, a split-plot design with PAR intensity as main plots and PB concentration as subplots and three replications was used. The experiment was set up under a full spectrum fluorescent light bank (ParaLite Maxum 5000 bulbs; Full Spectrum Solutions, Jackson, Mich.) as the sole irradiation source providing $120 \mu \mathrm{mol} \cdot \mathrm{m}^{-2} \cdot \mathrm{s}^{-1}$ at the flat surface level for 12.5 $\mathrm{h} \cdot \mathrm{d}^{-1}$. Temperatures were set at $20^{\circ} \mathrm{C}$ night and $21^{\circ} \mathrm{C}$ day. Four PAR intensities $(120,70,50$, or $0.09 \mu \mathrm{mol} \cdot \mathrm{m}^{-2} \cdot \mathrm{s}^{-1}$ ) were achieved by not covering the seeded flats, covering with wooden frames with one or two layers black fiberglass window screen, or covering with $6 \mathrm{~mm}$ black plastic respectively. PAR was measured at flat surface level using a quantum photometer (LI188B; LI-COR, Lincoln, Neb.). The wooden frames were $45 \mathrm{~cm}$ square and $30 \mathrm{~cm}$ tall. Ten treated seeds of each PB treatment were planted in 288 cell flats cut in half with divisions of ten cells made with tape. Each half flat had nine divisions. The PB treatments were randomly assigned within each flat. The different PAR intensities were randomly assigned to the flats. The flats were placed on capillary mat for irrigation and two fertilizations at $200 \mathrm{mg} \mathrm{N} / \mathrm{L}$ from $20 \mathrm{~N}-4.4 \mathrm{P}-16.6 \mathrm{~K}$ were applied during the growing period. Emergence counts were taken at 7 and $14 \mathrm{~d}$ after sowing. Seedlings were harvested at $25 \mathrm{~d}$ after sowing due to excessive elongation in the low PAR treatments. Hypocotyl length and total seedling height were measured.

Data collected were analyzed as a splitplot using Proc Mixed of SAS (SAS Institute, Cary, N.C.).

\section{Results and Discussion}

PB concentration and duration. Initial $(0 \mathrm{hr})$ electrical conductivity (EC) of the PB solution increased as $\mathrm{PB}$ concentration increased. The change in electrical conductivity $(\triangle \mathrm{EC})(\Delta \mathrm{EC}$ $=$ initial $\mathrm{EC}-$ final $\mathrm{EC}$ ) represents the relative increase in $\mathrm{EC}$ due to electrolyte leakage from the seed. While there was a consistent gain in $\mathrm{EC}$ after soaking, the net gain, represented by $\triangle \mathrm{EC}$, decreased as $\mathrm{PB}$ concentration increased (Fig. 1). This was consistent for each soaking time. Paclobutrazol concentration affected the amount of electrolyte leakage from tomato seed. At $0 \mathrm{mg} \mathrm{PB} / \mathrm{L}$, electrolyte leakage occurred rapidly and after $1 \mathrm{~h}$ of soaking time there was no additional increase in $\triangle \mathrm{EC}$ (Fig. $1)$. With the addition of $\mathrm{PB}, \triangle \mathrm{EC}$ increased as soaking time increased. However, less total electrolytes leaked as PB concentration increased. Seed treatment with $P B$ reduced the amount and rate of electrolyte leakage during treatment compared to the control. Reduced electrolyte leakage has been shown to result in more vigorous and better germination (Bewley and Black, 1985). Meints et al. (2002) found that electrolyte leakage was negatively correlated with soybean seedling emergence in cool, wet soil conditions. Limited electrolyte leakage from seed may reduce pathogen infection after planting. Also, Fletcher and Hofstra (1990) found that treating wheat seed with a triazole improved seedling resistance to heat stress and chilling injury.

Emergence of seedlings was not affected by either PB concentration or soaking time at 7 and 14 d after planting (93\% mean emergence). Kepzynski and Kepzynska (1989) found that germination of Amaranthus paniculatum treated with $\mathrm{PB}$ at $3 \times 10^{-4} \mathrm{~mol}\left(88 \mathrm{mg} \cdot \mathrm{L}^{-1}\right)$ was inhibited. They concluded that in this species, newly synthesized GAs are responsible for germination. In tomato, Pasian and Bennett (2001) found that 500 to $1000 \mathrm{mg}$ $\mathrm{PB} / \mathrm{L}$ inhibited germination when seeds were germinated on blotter paper. They speculated that PB adhered to the seedcoat was released into the blotter paper reaching concentrations which inhibited germination. While Pasian and Bennett (2001) found that germination in the lab was inhibited as PB concentration and soaking time increased, in the current study, neither PB concentration nor soaking time affected germination of 'Better Boy' tomato. This is similar to the findings of Groot and Karssen (1987) and Still and Pill (2003). The

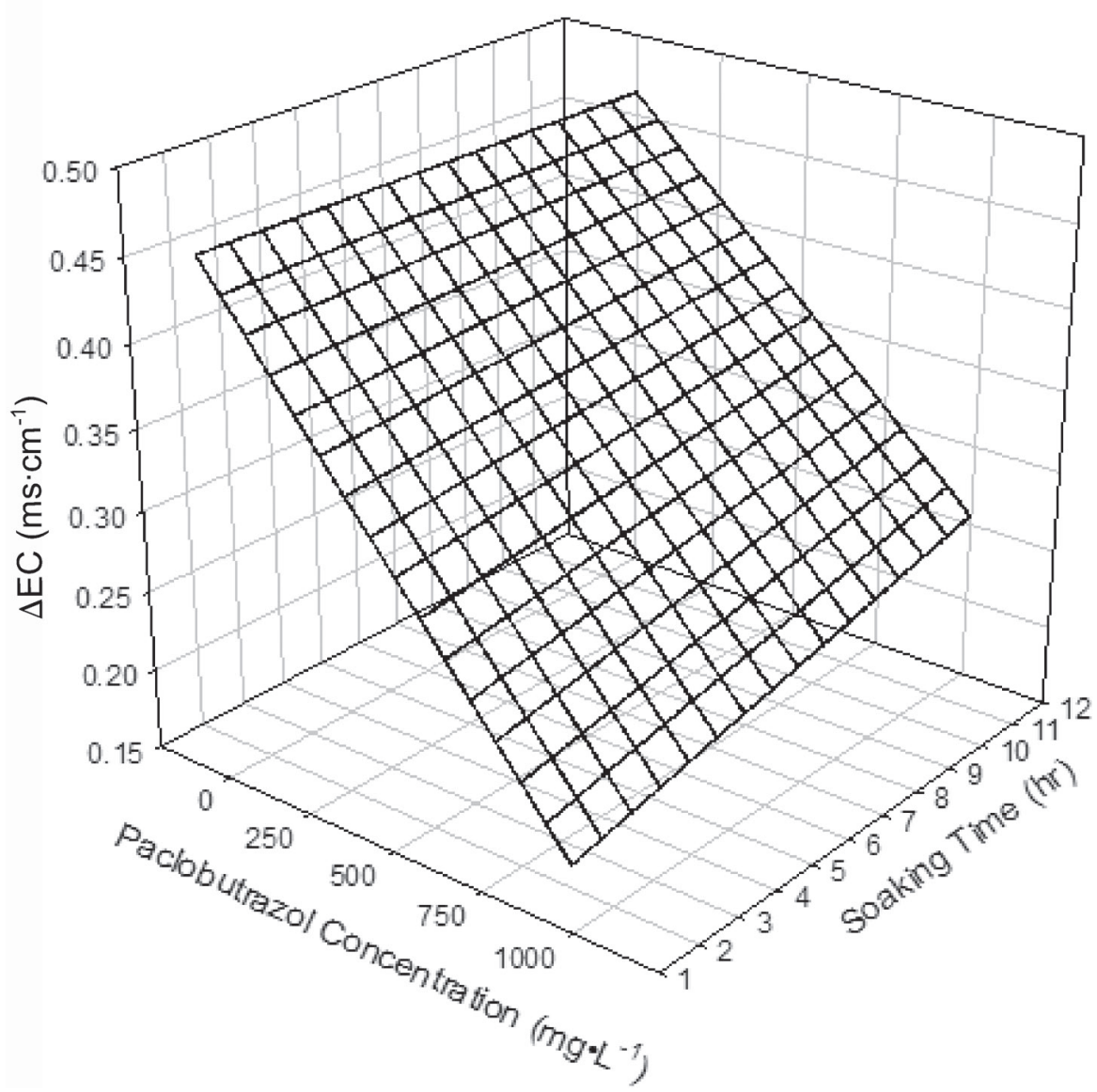

Fig. 1. Change in electrical conductivity $(\Delta \mathrm{EC})\left(\mathrm{ms}^{\cdot} \mathrm{cm}^{-1}\right)$ of the soaking solution as affected by tomato seed soak treatment at different paclobutrazol $(\mathrm{PB})$ concentrations $\left(\mathrm{mg} \cdot \mathrm{L}^{-1}\right)$ and soaking times (hours). $\mathrm{z}=$ $0.0000058 \mathrm{xy}-0.000278 \mathrm{x}+0.464(\mathrm{x}=\mathrm{PB}$ concentration, $\mathrm{y}=$ soaking time, $\mathrm{z}=\Delta \mathrm{EC}) r^{2}=0.71$. 


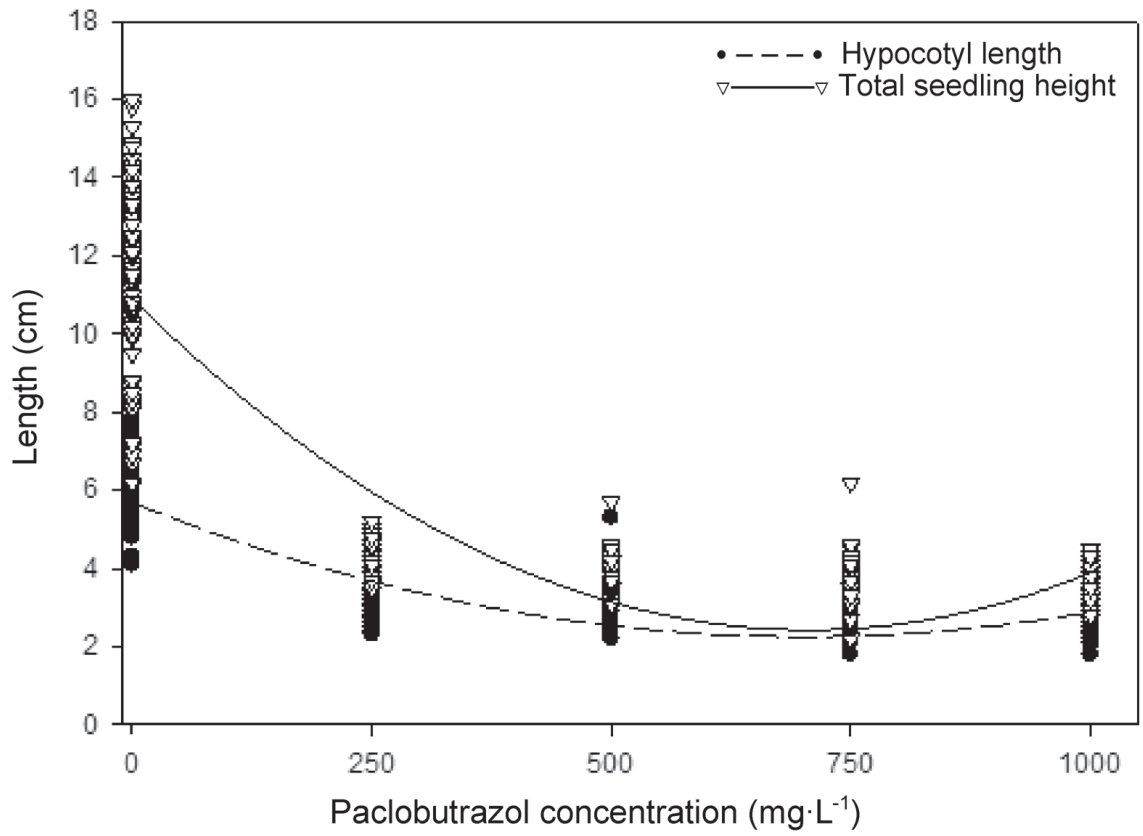

Fig. 2. Tomato hypocotyl length and total seedling height $35 \mathrm{~d}$ after planting as affected by paclobutrazol (PB) seed soak treatment. Hypocotyl length $\mathrm{y}=0.000007 \mathrm{x}^{2}-0.0098 \mathrm{x}+5.682(\mathrm{x}=\mathrm{PB}$ concentration $)$ $r^{2}=0.82$; Total seedling height $\mathrm{y}=0.000017 \mathrm{x}^{2}-0.024 \mathrm{x}+10.896(\mathrm{x}=\mathrm{PB}$ concentration $) r^{2}=0.81$.

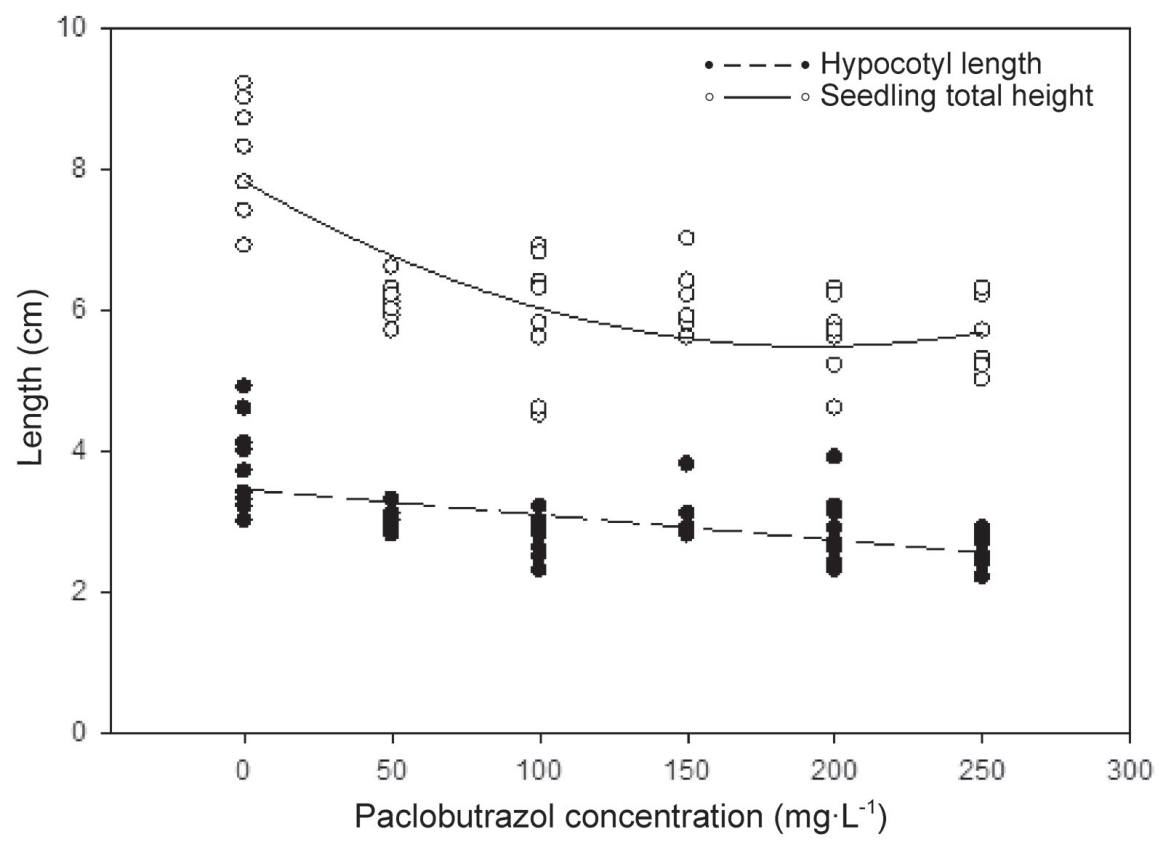

Fig. 3. Tomato hypocotyl length and total length $35 \mathrm{~d}$ after planting as affected by paclobutrazol (PB) seed soak treatment. Hypocotyl length $\mathrm{y}=-0.0036 \mathrm{x}+3.443(\mathrm{x}=\mathrm{PB}$ concentration $) r^{2}=0.44$; total length $\mathrm{y}=0.000063 \mathrm{x}^{2}-0.0243 \mathrm{x}+7.817(\mathrm{x}=\mathrm{PB}$ concentration $) r^{2}=0.69$.

main action of GA in germination of tomato seeds is the weakening of the endosperm layer surrounding the radicle tip allowing the radicle to protrude. The development of the embryo is not dependent on newly synthesized GA(Groot and Karssen, 1987; Groot et al., 1988). Since $\mathrm{PB}$ was applied to the seed, the inhibition of GA biosynthesis will affect synthesis of GA and not preexisting GA present in the seed. Therefore, endogenous (preexisting) GA in the embryo and endosperm is available for germination. In addition, Pasian and Bennett (2001) reported that PB seed soak for 6 and
$16 \mathrm{~h}$ had no effect on the percentage of usable seedlings but when seeds were soaked for $24 \mathrm{~h}$ the percentage decreased. In the current study, soaking up to $12 \mathrm{~h}$ had no negative effect on emergence.

Seedling hypocotyl elongation at $35 \mathrm{~d}$ after planting was restricted by $\mathrm{PB}$ application (Fig. 2). Hypocotyl length was most restricted between 0 and $250 \mathrm{mg} \mathrm{PB} / \mathrm{L}$. At concentrations $>250 \mathrm{mg} \mathrm{PB} / \mathrm{L}$ there was no significant additional restriction of hypocotyl elongation. Soaking time had no effect on seedling hypocotyl elongation (data not shown).
Seedling height decreased as PB concentration increased (Fig. 2). The greatest growth suppression occurred between 0 and $250 \mathrm{mg}$ $\mathrm{PB} / \mathrm{L}$. At greater concentrations, there was no additional suppression of seedling height.

Residual PB effects. Emergence of tomato seedlings at 7 and $14 \mathrm{~d}$ after seeds were sown was unaffected by 0 to $250 \mathrm{mg} \mathrm{PB} / \mathrm{L}$ ( $92 \%$ emergence; data not shown). Hypocotyl length $35 \mathrm{~d}$ after seeds were sown decreased as PB concentration increased(Fig. 3). Total seedling height after $35 \mathrm{~d}$ was reduced at as low as 100 mg PB/L (Fig. 3).

At first flower anthesis, as $\mathrm{PB}$ concentration increased, the length of the first three internodes decreased (Fig. 4). None of the internodes above the third internode was affected by PB concentration (data not shown). Leaf area and days to flower were not affected by PB concentration of the soaking solution (data not shown). Research by Pill and Gunter (2001), Still and Pill (2003), and Passian and Bennett (2001) suggested the need for higher PB concentrations for effective long term height control, however, neither nor grew treated seedlings for longer than $36 \mathrm{~d}$.

Since $P B$ binds reversibly to organic matter (Lever, 1986) we speculate that PB adhered to the seedcoat during soaking and was released to the soil upon sowing and taken up by the radicle, acting similar to a soil drench. When applied as a soil drench, PB uptake is determined by factors that affect its movement in the soil. The proximity of $\mathrm{PB}$ to the roots determines its effectiveness (Lever, 1986). PB moves easily through the xylem via the transpiration stream (Barrett and Bartuska, 1982). This study shows that small amounts of PB applied to the seed effectively moved to the site of action controlling seedling height and internode length with limited long term effect. No negative effects on flowering (date to first flower and number of internodes to first flower) were observed due to PB treatments.

PAR intensity. Seedling emergence at 7 and $14 \mathrm{~d}$ after planting was not affected by PB soaking solution concentration $(72 \%$ emergence, data not shown).

Seedlings grown under very low (0.09 $\mu \mathrm{mol} \cdot \mathrm{m}^{-2} \cdot \mathrm{s}^{-1}$ ) PAR intensity had longer hypocotyls at $25 \mathrm{~d}$ after sowing than any other treatment and were unaffected by soaking seeds in 0 to $250 \mathrm{mg} \mathrm{PB/L}$ for $1 \mathrm{~h}$ (Fig. 5). Seed germination and the lack of control of hypocotyl elongation under near dark conditions indicates that the PB most likely affects postemergence GA synthesis and not the conversion of stored GA to an active form.

Increasing PAR was associated with decreasing hypocotyl length and seedling height. Seedlings did not develop an epicotyl when grown under very low PAR levels $\left(0.09 \mu \mathrm{mol} \cdot \mathrm{m}^{-2} \cdot \mathrm{s}^{-1}\right)$ while at $50 \mu \mathrm{mol} \cdot \mathrm{m}^{-2} \cdot \mathrm{s}^{-1}$ PAR, epicotyl development was normal. As PB concentration increased, seedling total height decreased under all PAR intensities $\geq 50$ $\mu \mathrm{mol} \cdot \mathrm{m}^{-2} \cdot \mathrm{s}^{-1}$ (Fig. 6).

When treated seeds of 'Better Boy' tomato were germinated under different PAR intensities to determine the efficacy of the PB seed soak treatment under adverse light conditions, the $\mathrm{PB}$ 

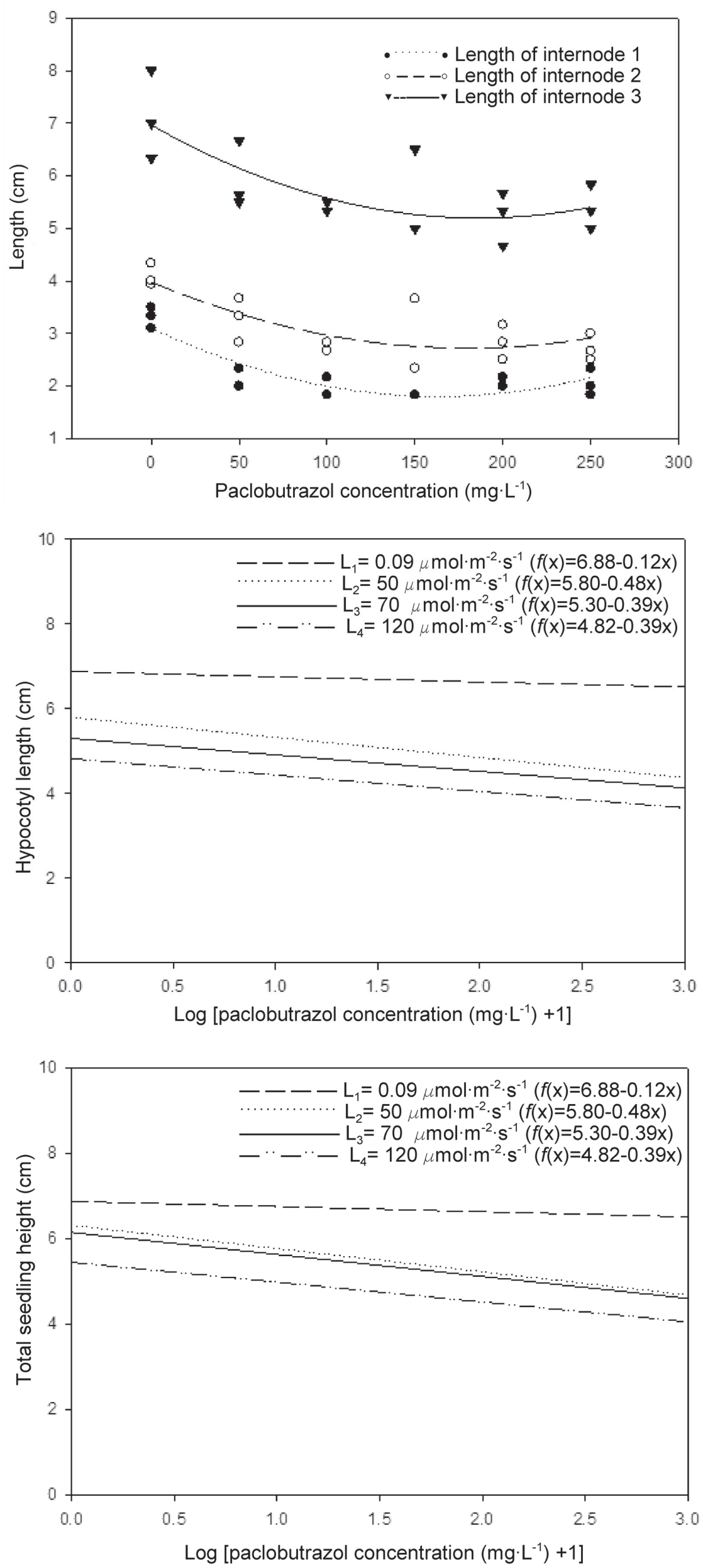

Fig. 4. Residual effects of paclobutrazol (PB) seed soak treatment on tomato internode elongation measured at flowering. first internode length y $=0.000049 \mathrm{x}^{2}-0.016 \mathrm{x}+3.11\left(r^{2}=0.69\right)$; second internode length $\mathrm{y}=0.000039 \mathrm{x}^{2}-0.014 \mathrm{x}$ $+3.98\left(r^{2}=0.57\right)$; third internode length $\mathrm{y}=$ $0.000051 \mathrm{x}^{2}-0.019 \mathrm{x}+6.967\left(r^{2}=0.50\right)(\mathrm{x}=$ $\mathrm{PB}$ concentration).

Fig. 5. Hypocotyl length of tomato seedlings grown under different light $\left(\mathrm{L}_{\mathrm{v}}\right)$ levels $(0.09,50,70$, or $\left.120 \mu \mathrm{mol} \cdot \mathrm{m}^{-2} \cdot \mathrm{s}^{-1}\right)$ as affected by a paclobutrazol (PB) seed soak treatment $(0,12.5,25,37.5,50$, $100,150,200$, or $\left.250 \mathrm{mg} \cdot \mathrm{L}^{-1}\right)$. PB data transformed using $\log (\mathrm{x}+1) .\left(r^{2}=0.93\right)$.

Fig. 6. Tomato seedling total height $(\mathrm{cm})$ as affected by seed soak treatment with paclobutrazol (PB) concentrations $0,12.5,25,37.5,50,100,150$, 200 , or $250 \mathrm{mg} \cdot \mathrm{L}^{-1}$ and grown under light conditions of $0.09,50,70$, or $120 \mu \mathrm{mol} \cdot \mathrm{m}^{-2} \cdot \mathrm{s}^{-1}$. PB data transformed using $\log (\mathrm{x}+1) .\left(r^{2}=0.90\right)$. 
treatment had the greatest effect on seed germinated under $50 \mu \mathrm{mol} \cdot \mathrm{m}^{-2} \cdot \mathrm{s}^{-1} \mathrm{PAR}$. Seedling height control was noticeable as measured by both hypocotyl length and seedling total height under varying PAR conditions (50, 70, and 120 $\left.\mu \mathrm{mol} \cdot \mathrm{m}^{-2} \cdot \mathrm{s}^{-1}\right)$. As the PAR levels increased, the effect on hypocotyl length and seedling height, due to PB seed soak, decreased.

Our results show that $\mathrm{PB}$ seed soak treatment at $100 \mathrm{mg} \cdot \mathrm{L}^{-1}$ prevented early stretch of tomato seedlings and had limited long term effect on plant growth. This treatment was effective in preventing excessive hypocotyl elongation when seeds were germinated under low PAR conditions. Paclobutrazol applied as a seed soak treatment may be used preemptively to reduce the further use of PGRs especially during the first stages of plug production. This technique may be effective for use on other species which experience excessive hypocotyl elongation during plug production.

\section{Literature Cited}

Arteca, R.N. 1996. Plant growth substances: principles and applications. Chapman \& Hall, New York.

Barrett, J.E. and C.A. Bartuska. 1982. PP333 Effects on stem elongation dependent on site of application. HortScience 17:737-738.

Bensen, R.J., D.B. Federick, J. E. Mullet, and P.W. Morgan. 1990. Detection of endogenous gibberellins and their relationship to hypocotyl elongation in soybean seedlings. Plant Physiol. 94:77-84.

Bewley, D.J. and M. Black. 1985. Seeds: physiology of development and germination. Plenum Press, New York.

Davis, T.D., F.L. Steffons, and N. Sankhla. 1988. Triazole plant growth regulators, p. 63-105. In: J. Janick (ed.). Horticultural reviews. Timber Press, Portland, Ore.

Dole, J. and H.F. Wilkins. 1999. Floriculture: principles and species. Prentice Hall, Upper Saddle River, N.J.

Fletcher, R.A. and G. Hofstra. 1990. Improvement of uniconazole-induced protection in wheat seedlings. J. Plant Growth Regulat. 9:207--212.

Groot, S.P.C. and C.M. Karssen. 1987. Gibberellins regulate seed germination in tomato by endosperm weakening: a study with gibberellindeficient mutants. Planta 171:525-531.

Groot, S.P.C., B. Kieliszewska-Rokicka, E. Vermeer, and C.M. Karssen. 1988. Gibberellin-induced hydrolysis of endosperm cell walls in gibberellindeficient tomato seeds prior to radicle protrusion. Planta 174:500-504.

Kepzynski, J. and E. Kepzynska. 1989. Inhibitory effect of paclobutrazol on Amaranthus paniculatus L. seed germination and its reversal by $\mathrm{GA}_{3}$ and ethephon. Acta Hort. 251:47-51.
Lever, B.G. 1986. 'Cultar'—A technical overview. Acta Hort. 179:459-467.

Meints, P.D., L.E. Trevathan, and F.W. Maideni. 2002. Use of the conductivity test to estimate soybean seed emergence and resistance to infection by Fusarium oxysporum in the southern United States. Plant Protection Qrtly. 17:64-66.

Pasian, C.C. and M.A. Bennett. 2001. Paclobutrazol soaked marigold, geranium, and tomato seeds produce short seedlings. HortScience 36:721-723.

Pill, W.G. and J.A. Gunter, Jr. 2001. Emergence and shoot growth of cosmos and marigold from paclobutrazol-treated seed. J. Environ. Hort. 19:11-14.

Still, J.R. and W.G. Pill. 2003. Germination, emergence, and seedling growth of tomato and impatiens in response to seed treatment with paclobutrazol. HortScience 38:1201-1204.

Styer, R.C. and D.S. Koranski. 1997. Plug and transplant production. Ball Publ., Batavia, Ill.

Toyomasu, T., H. Tsuji, H. Yamane, M. Nakayama, I. Yamagchi, N. Morofushi, N. Takahashi, and Y. Inoue. 1993. Light effects on endogenous levels of gibberellins in photoblastic lettuce seed. J. Plant Growth Regulat. 12:85-90.

Toyomasu, T., H. Yamane, I. Yamagushi, N. Murofushi, N. Takahashi, and Y. Inoue. 1992. Control by light of hypocotyl elongation and levels of endogenous gibberellins in seedlings of Lactuca sativa L. Plant Cell Physiol. 33:695-701. 